\title{
THE IMPACT OF COVID-19 PANDEMIC ON THE GLOBAL ECONOMY: EMPHASIS ON POVERTY ALLEVIATION AND ECONOMIC GROWTH
}

\author{
Prince Asare \\ Vitenu-Sackey ${ }^{1+}$ \\ Richard Barfi ${ }^{2}$
}

\author{
${ }^{1,2}$ School of Finance and Economics, School of Management, Jiangsu \\ University, Zhenjiang, Jiangsu Province, P. R. China. \\ 'Email.parsackey@gmail.com \\ sEmail: richiebars@@yahoo.com
}

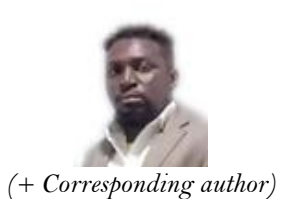

Article History

Received: 2 November 2020 Revised: 25 November 2020 Accepted: 15 December 2020 Published: 4 January 2021

\section{Keywords}

Stringency Index COVID-19 Pandemic Human development Index Economic growth Poverty Alleviation.

JEL Classification: O49; I30.

\section{ABSTRACT}

The COVID-19 pandemic has devastated the global economy, which has rendered many of the world's population impoverished. Moreover, the pandemic has generated some uncertainties regarding economic and social policies. This phenomenon is lately the brunt of every government across the globe. This present study seeks to evaluate the pandemic's impact on poverty alleviation and the global GDP by considering individual countries' heterogeneous effects in a panel study. The motivation is to unravel the social and economic effects on the global economy. However, 170 countries are utilized in this study, and econometric panel techniques such as OLS and robust least square regression methods are utilized. The data was collected from OurWorldindata.com, comprising total COVID-19 cases, total deaths, stringency index, human development index, and gross domestic product per capita. The study's findings stipulate that many people's stringency and the contraction of the disease have inversely affected poverty alleviation and economic growth. Nevertheless, for the deaths recorded so far positively affects both poverty alleviation and economic growth. This development signals the essence of controlling population growth as it impedes economic growth and poverty alleviation. The study recommends that governments invest in health and education improvement and stimulate their economies to create employment that could propagate growth to improve poverty alleviation and economic growth.

Contribution/Originality: This study contributes to the existing literature and presents the long-run impact of COVID-19 pandemic on economic growth and poverty alleviation in the global context.

\section{INTRODUCTION}

The Global COVID-19 pandemic has infected millions of the world's population at a shocking speed. Its emergence has halted and brought down economic activities across the globe due to the imposition on mobility to curtail the disease's spread. Over some decades, the world has not witnessed such an experience. However, it has a significant toll on various economies due to shocks emanating from deteriorating human and health conditions (World Bank, 2020). This pandemic is exceedingly a health crisis but social and economic crises due to the effects it has had on lives and economies at large. Moreover, the pandemic's impact would be heterogeneous from country to country, and it is likely to widen inequalities and poverty globally. This development would stall the progress made to achieve the Sustainable Development Goals, requiring much attention and urgent response (United Nations Development Programme, 2020). According to Sarkodie and Owusu (2020), the nexus of environment-healtheconomic impact on human lives and countries at large have become necessary due to the emergence of the COVID- 
19 pandemic. Since the global pandemic brought about the need to show much concern about the consequences surrounding the environment, health, and economy (Wang, Horby, Hayden, \& Gao, 2020). As of December 18, 2020, the number of COVID-19 cases recorded worldwide stands at 72,851,747, and the number of deaths stands at $1,643,339$, whereas the United States of America suffered most with a total number of 16,446,844 representing $22.58 \%$ of the total cases, and 301,536 deaths representing $18.35 \%$ of the total deaths in the world with India, Brazil, Russia, and France follow suit as the top five countries with the most cases in the world see Figure 1.

\begin{tabular}{|c|c|c|c|c|}
\hline Name & $\begin{array}{l}\text { Cases - } \\
\text { cumulative total } \equiv \downarrow\end{array}$ & $\begin{array}{l}\text { Cases - newly } \\
\text { reported in last } 24 \\
\text { hours }\end{array}$ & $\begin{array}{l}\text { Deaths - } \\
\text { cumulative total }\end{array}$ & $\begin{array}{l}\text { Deaths - newly } \\
\text { reported in last } 24 \\
\text { hours }\end{array}$ \\
\hline Global & $72,851,747$ & 642,738 & $1,643,339$ & 12,407 \\
\hline 를 United Stat... & $16,446,844$ & 201,468 & 301,536 & 2,942 \\
\hline India & $9,956,557 \square$ & 24,010 & 144,451 & 355 \\
\hline (2) Brazil & $6,970,034 \square$ & 42,889 & 182,799 & 964 \\
\hline Russian $\mathrm{Fe} \ldots$ & $2,762,668$ & 28,214 & 49,151 & 587 \\
\hline France & $2,367,648$ & 17,441 & 58,989 & 289 \\
\hline
\end{tabular}

Source: World Health Organisation (2020).

Figure-1. COVID-19 updates as at 18/12/2020.

The global pandemic has simultaneously disrupted both demand and supply in the global economy. Based on the supply side, the disruptions resulted from the infections, which reduced labor productivity and supply. The restrictions imposed on mobility, social distancing, and business closures disrupted the supply of goods and services. On the demand side, loss of income and layoffs resulted from quarantines, morbidity and unemployment, and reduced firms' investments and household consumption due to worsened economic prospects (Chudik, Mohaddes, Pesaran, Raissi, \& Rebucci, 2020). Moreover, the stringent measures instituted to curtail the spread such as travel ban, quarantine, lockdown, movement restrictions, social distancing, and close down of public events and public places in other ways affected economic development and environmental sustainability (Gautam \& Hens, 2020; Gautam. \& Trivedi, 2020; Sarkodie \& Owusu, 2020).

According to the Global Economic Prospects (World Bank, 2020), the global economy envisages a 5.2\% contraction in the gross domestic product (GDP) despite various governments' extraordinary interventions to tackle monetary and fiscal effects policy assistances. That notwithstanding, the aftermath of the pandemic is projected to leave an indelible mark on the global economy by destroying human capital resulting from loss of schooling and work, lower investment, and disintegration of global supply and trade linkages (World Bank, 2020). Sarkodie and Owusu (2020) contend that the restrictions and stringent measures instituted to curtail the spread of the COVID-19 virus through social distancing and lockdown have severe economic, environmental, and health impacts on the global population. The lockdown effect has contributed tremendously to the strengthening of healthcare systems and led to the reduction of emissions. Even though the pandemic has caused some havoc, it has led to great lessons to necessitate economic relief measures to ensure the deterioration of economic development strides chalked.

The pandemic's impact has an extreme uncertainty about the length, path, and extent, which could develop a vicious cycle of tightening financial conditions and dampening consumer and business confidence; this could lead to 
investment and job losses (Chudik et al., 2020). The possible questions that any empirical study would seek to answer are; (i) what unprecedented shocks have the pandemic caused considering the cross-country spillovers? (ii) how to quantify the unprecedented uncertainty concerning forecasts? Figure 2 depicts the uncertainty level that the pandemic has caused the world. The figure shows that the COVID-19 pandemic has caused an outrageous uncertainty more than any other pandemic experienced. Comparing the COVID-19 pandemic to SARS, which somewhat caused heightened uncertainty in 2002 and 2003, is unmatched. The levels of the COVID-19 far exceed any other pandemic experienced globally.

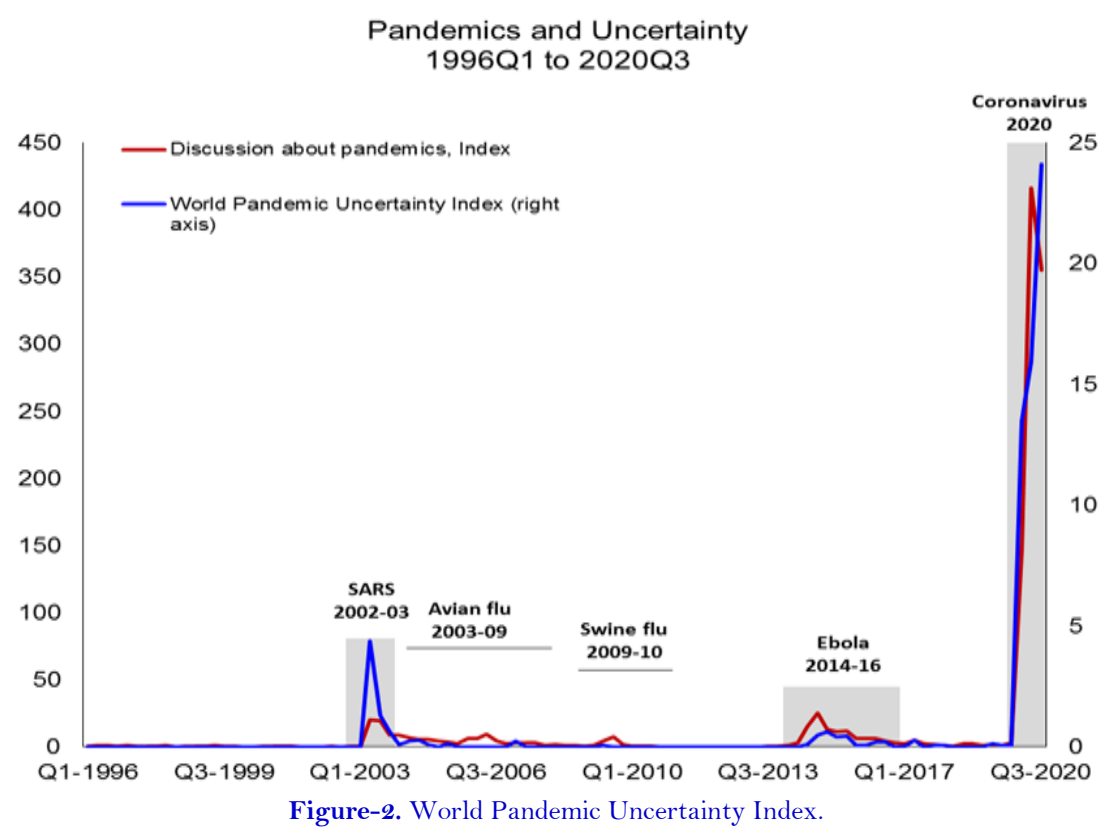

Upon reviewing existing literature, it is evident that numerous studies have identified the immediate and longrun impact of the pandemic on the global economy and other spheres of life. However, none of them have identified the exact cost per capita daily. Therefore, this present study seeks to estimate the long-run cost per capita regarding output and human development deterioration. Moreover, this present study utilized an econometric approach to assessing the pandemic's impact on the global economy and poverty alleviation since most studies pursue a descriptive discussion of the pandemic's devastating effect.

The study aims to quantify the pandemic shocks on the global economy and poverty alleviation using econometric techniques such as ordinary least square and robust least square regression methods.

\subsection{The Economic Impact of COVID-19 Pandemic}

Although there is no way to prove precisely the economic fallout from the global pandemic of the latest COVID-19 coronavirus, there is a consensus among economists that it would have significant adverse effects on the global economy. Initial projections estimated that should the virus has become a global pandemic, many industrialized nations will lose approximately $2.4 \%$ of the worth of their gross domestic product (GDP) by 2020, causing experts to lower their global economic growth expectations for 2020 from about 3.0\% to 2.4\%. Global GDP was projected at around 86.6 trillion U.S. dollars in 2019 to put this figure in perspective, indicating that only a $0.4 \%$ decline in economic growth corresponds to about 3.5 trillion U.S. dollars in lost economic production. However, these forecasts were made before COVID-19 became a global pandemic and before introducing mass public interaction restrictions to avoid the transmission of the virus. Since then, due to the incidence, global stock markets have experienced dramatic declines. On March 16, 2020, the Dow Jones recorded its largest-ever single- 
day decline of nearly 3,000 points, breaking its existing 2,300-point record, which was achieved some days before (Statista, 2020).

The pandemic has heightened economic fallouts causing a global crisis whereby people are losing their lives and others experiencing unemployment due to the collapse of businesses because of the disruption in demand and supply. Therefore, the pandemic is not only a health issue but a socio-economic issue suppressing the global sustainable development agenda (Nicola, 2020; Pirouz, 2020). The much anticipated strong healthcare system in the advanced economies suffered tremendously due to the pandemic's emergence. Most medical officers were left in a dilemma to decide the patient who needs to survive. The inexistence of a keen vaccine to stop the spread of the virus has caused high uncertainty globally because countries across the globe do not follow any reliable exit strategy (Mofijur et al., 2020). The pandemic has sent the most vulnerable and marginalized people into more deplorable states, such as persons with disabilities, older-aged persons, youths, ethnic minorities, and indigenous people. Tragically, persons with no form of accommodation, such as migrants, refugees, or displaced persons, suffer excessively during the pandemic and will continue to suffer the aftermath of the pandemic. These developments are in existence as a result of loss of employment, mobility restrictions and burgeoning rate of xenophobic experiences. Indeed this pandemic is exceedingly an economic havoc but also social problem which is widening the inequality gap in long-term and medium if proper measures are not put in place to curtail it exigently.

As discussed previously, the stringency measures to curtail the widespread of the virus are affecting economies severely across the world. A stringency policy like the lockdown has affected productivity levels through workers' restriction to stay in their various homes to work instead of their workplaces. Also, the restrictions on public gatherings, the imposition on travel bans, restriction on the attendance of public events and tourist attraction site visits have contributed negatively to the hospitality and tourism sectors where most businesses have encountered a decline in their business activities by almost 90\% (Fernandes, 2020). Most especially, businesses are dependent on social engagements, specifically in the tourism and entertainment sectors have experienced downturns, and most of their employees have lost their livelihood through job redundancy and layoffs. This has resulted in a decline in consumption of their casualties and increased the uncertainty of people to spend, which caused many businesses to close down and fallout (Ghosh, 2020). In place of this, most countries have projected to experience a sharp decline in economic growth, dipping their gross domestic product.

Consequently, the global economy is expected to contract by $3 \%$ at the end of 2020 and exceedingly severe than the global financial crisis that occurred in 2008 (International Monetary Fund (IMF), 2020). However, the global economic giants have suffered the most in the wake of the pandemic. It is estimated that Spain, Italy, France, Germany, the United Kingdom, Japan, and the United States of America would experience contraction in the economy by $8.0 \%, 9.1 \%, 7.2 \%, 7.0 \%, 6.5 \%, 5.4 \%$, and 5.9\%, respectively (International Monetary Fund (IMF), 2020).

In the wake of some countries' pandemic, governments alleviated the pandemic's economic impact on their citizens. Figure 3 depicts the world map and explicitly illustrates the countries that provided some interventions and economic supports to their citizens. From the map, it can be observed that the illustration is categorized into four; thus countries without data, countries with no income support to their citizens, countries that offered income support less than $50 \%$ of the salaries of the beneficiaries, and countries that offered income support more than $50 \%$ of the beneficiaries' salaries. Countries like Greenland, Algeria, Nigeria etc., did not provide any income support to their citizens. However, China, Russia, Uzbekistan etc., provided less than $50 \%$ of the salaries of affected citizens, and Canada, U.S, France, Spain, Norway etc., provided more than $50 \%$ of the salaries of affected citizens.

Inevitably, it is likely impossible to mitigate the adverse impact of the pandemic on the global economy. That notwithstanding, governments have devised economic recovery strategies such as pumping funds into the economy through stimulus packages to alleviate the citizens' plights and save lives. Imperatively, the response packages are significant economic stimulus initiatives that governments across the globe are embarking on to curtail the deterioration of human development and the economic downturn as a result of the COVID-19 pandemic. 

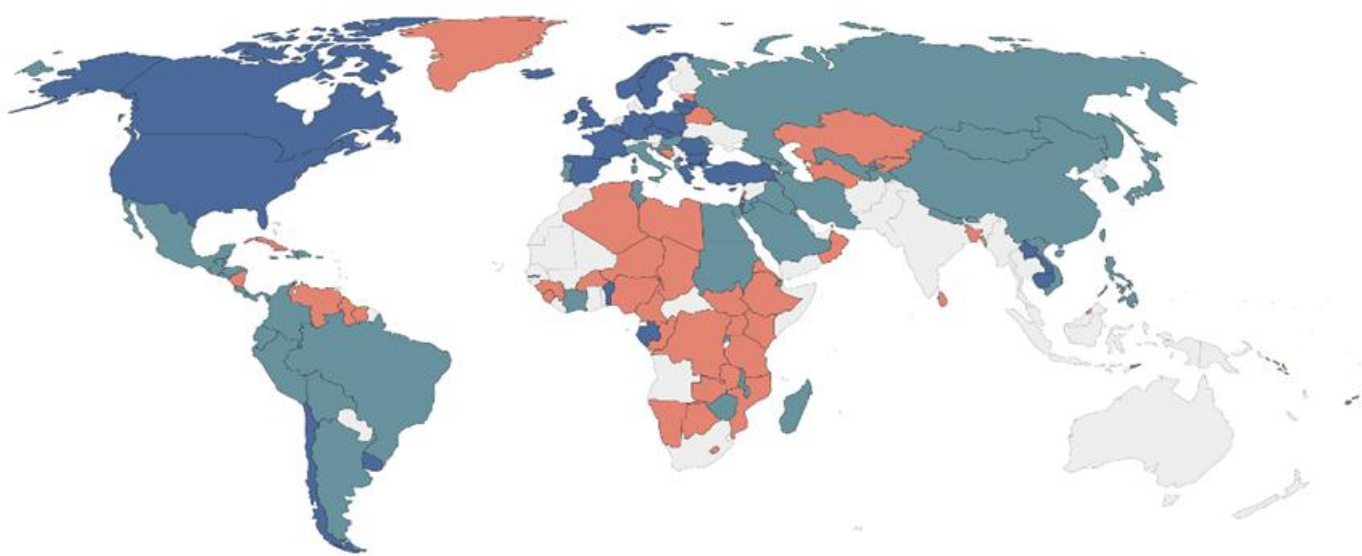

No data

No income support

Covers $<50 \%$ of lost salary

Covers $>50 \%$ of lost salary

Figure-3. Countries' income support map (Source: Our World in Data).

Source: Hale, Webster, Petherick, Phillips, and Kira (2020). Oxford COVID-19 Government Response Tracker-Last update December 18, 18:01 (London time).

Note: This income support may not apply to workers in all sectors and may vary at the sub-national level.

The major stimulus packages embarked on by governments includes monetary and fiscal policies centered on health care delivery, households consumption, servicing and manufacturing industries, liquidity support to banks, allocation of funds to households and businesses, infrastructural and funding support for healthcare delivery, and policies targeted at alleviating the cost of layoffs (Bayer, Born, Luetticke, \& Müller, 2020; Cheng, Barcelo, Hartnett, Kubinec, \& Messerschmidt, 2020; Elgin, Basbug, \& Yalaman, 2020). Apparently, the kind of stimulus packages across the globe varies depending on the countries' responses to the pandemic (Capano, Howlett, Jarvis, Ramesh, \& Goyal, 2020).

In Figure 4, the economic stimulus packages as a percentage of GDP provided by governments across the globe are presented. Countries that provided the highest economic stimulus packages are Bahrain, Malta, Austria, Luxembourg, France, Oman, Belgium, Sweden, Germany, and Malaysia as the top 10 countries with stimulus packages as a percentage of GDP ranging from 31.30, 25.61\%, 25.11\%, 22.91\%, 22.59\%, 22.59\%, 19.61\%, $18.65 \%$, $17.29 \%$, and $16.42 \%$, correspondingly. In obvious ways, governments' choices of economic stimulus packages were dependent on their economic stringencies and sovereign credit ratings to mitigate the economic turndown that resulted from the pandemic.

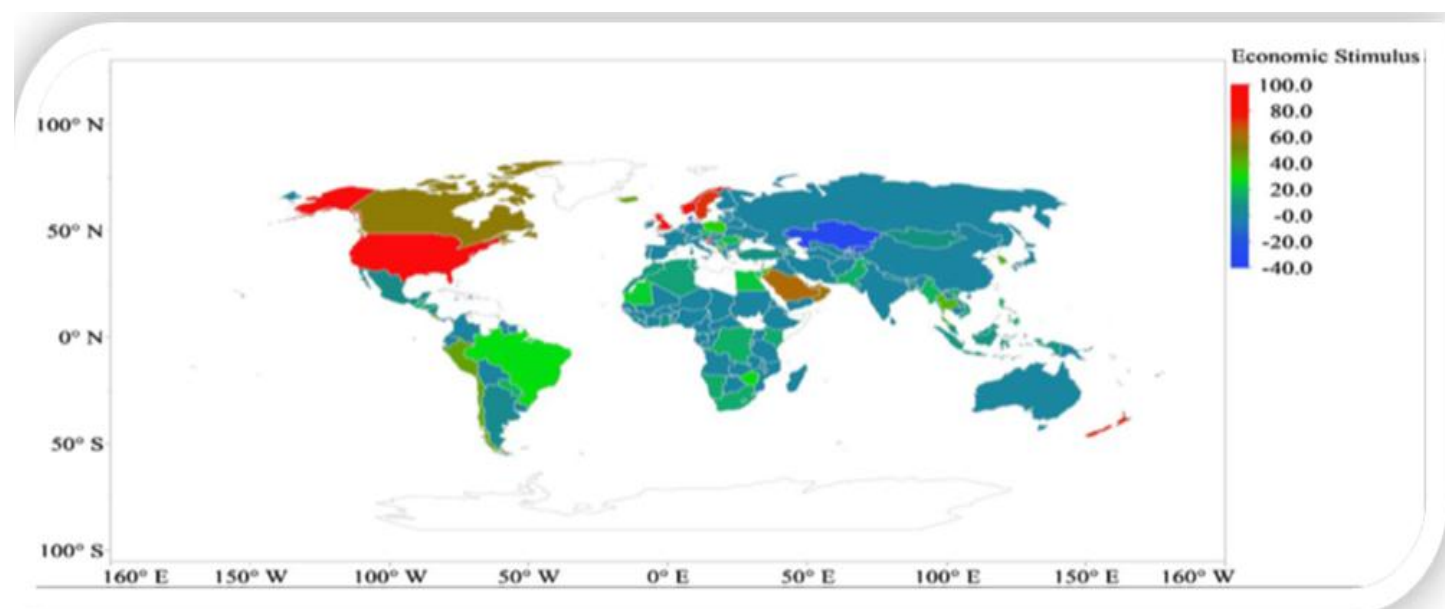

Figure-4. Economic stimulus packages \% of GDP global map.

Source: Sarkodie and Owusu (2020). 


\section{METHODOLOGY AND DATA}

\subsection{Methodology}

Some scholarly works concerning the impact of the COVID-19 pandemic on macroeconomics have emerged from the country-level and global levels. Specifically, some scholarly works concentrated on the pandemic effect on the U.S. stock market and critically assessed the economy's various impacts (Pagano, Wagner, \& Zechner, 2020). In another study, Ludvigson, Ma, and $\mathrm{Ng}$ (2020) evaluated the impact of the COVID-19 pandemic on the macroeconomy using the VAR framework.

From their findings, they contended that the COVID-19 pandemic shocks relate to past costly adversities. In a multi-sectoral model, Baqaee. and Farhi (2020) utilized a non-linearity approach to understanding the pandemic's impact on the U.S.'s aggregate data. They suggested that the shocks encountered by the pandemic could be mitigated in a non-linearity approach. Inadvertently, the COVID-19 pandemic has a spillover effect on the global economy, as identified by McKibbin and Fernando (2020) which is likely to manifest in the preceding years.

Due to the supply and demand side disruptions, the pandemic has caused the global economy to escalate into loss of jobs, loss of income, health, and education deterioration affecting human capital development (United Nations Development Programme, 2020). Moreover, causing an economic downturn sending the global economy into recession (World Bank, 2020). This study intends to quantify the impact of the pandemic on the global economy and poverty alleviation. Hence, the study constructs the model below for its econometric and empirical analysis;

$$
\begin{aligned}
& H D I_{i t}=\beta_{0}+\beta_{1} \text { COVID }-19 \text { PANDEMIC }_{i t}+\beta_{2} \text { GDPCAP }_{i t}+\varepsilon_{i t} \\
& G D P C A P_{i t}=\beta_{0}+\beta_{1} C O V I D-19 P A N D E M I C_{i t}+\beta_{2} H I_{i t}+\varepsilon_{i t} \text { (2) }
\end{aligned}
$$

In Equations 1 and 2 above $\beta_{0}$ constitutes the intercept of the slope or constant term, $\beta_{1}$ to $\beta_{2}$ are the elasticity coefficients of COVID-Pandemic, and Human development as the exogenous variables. $\boldsymbol{\varepsilon}$ constitutes the error term or the stochastic disturbance expected to occur in the model. Moreover, i represents the cross-section of 170 countries, and t represents the period under study; thus, 31/12/2019 to 19/10/2020. The ordinary least square regression method is used in the estimation.

The robust least square regression method is used as a robust check due to the OLS's weakness to check for cross-sectional heterogeneity and endogeneity issues in the panel. The OLS is an appropriate method for the estimation because a cointegration relationship could not be established (Mansouri, Crookes, \& Korakianitis, 2013; Salahuddin, Gow, \& Ozturk, 2015).

2.2. Data

Data used for this study was extracted from OurWorldinData.com. The length of the data for COVID-19 variables spans from 31/12/2019 to 19/10/2020, and the length of the data for the Human Development Index and GDP per capita are moving average values from 1990 to 2017.

The dependent variables are the human development index as a proxy to measure poverty alleviation (VitenuSackey \& Alhassan, 2019; Vitenu-Sackey., 2020) and gross domestic product (GDP) per capita as a proxy to measure economic growth. The independent variable is COVID-19 pandemic, and three proxies are used to measure it, thus the stringency index, the total confirmed cases worldwide, and the total confirmed death worldwide. Details about the various variable are present in Table 1. 
Table-1. Variables description and source.

\begin{tabular}{|c|c|c|c|}
\hline $\begin{array}{l}\text { Variable } \\
\text { Indicator }\end{array}$ & Description & Measurement & Source \\
\hline STI & $\begin{array}{l}\text { Stringency Index - This is a composite measure } \\
\text { based on nine response indicators, including } \\
\text { school closures, workplace closures, and travel } \\
\text { bans, rescaled to a value from o to } 100 \text { (100 = } \\
\text { strictest). If policies vary at the subnational level, } \\
\text { the index is shown as the strictest sub-regions } \\
\text { response level. }\end{array}$ & $\begin{array}{l}\text { COVID-19 Pandemic- } \\
\text { Lockdown }\end{array}$ & Hale et al. (2020). \\
\hline T.C. & $\begin{array}{l}\text { Total confirmed COVID-19 cases worldwide } \\
\text { from December } 312019 \text { to October } 192020\end{array}$ & $\begin{array}{l}\text { COVID-19 Pandemic- } \\
\text { Total cases recorded }\end{array}$ & $\begin{array}{l}\text { European Centre for } \\
\text { Disease Prevention } \\
\text { and Control (ECDC) }\end{array}$ \\
\hline T.D. & $\begin{array}{l}\text { Total deaths recorded from December } 312019 \text { to } \\
\text { October } 192020\end{array}$ & $\begin{array}{ll}\text { COVID-19 } & \text { Pandemic- } \\
\text { Deaths- } & \text { Population } \\
\text { Reduction } & \\
\end{array}$ & $\begin{array}{l}\text { European Centre for } \\
\text { Disease Prevention } \\
\text { and Control (ECDC) }\end{array}$ \\
\hline GDPCAP & $\begin{array}{l}\text { Gross domestic product per capita at constant } \\
\text { prices } 2011 \text { International dollars }\end{array}$ & Economic Growth & $\begin{array}{l}\text { World Development } \\
\text { Indicators - World } \\
\text { Bank }\end{array}$ \\
\hline HDI & $\begin{array}{l}\text { Human Development Index - composite measure } \\
\text { of education, life expectancy at birth, and per } \\
\text { capita income indicators }\end{array}$ & Poverty Alleviation & $\begin{array}{l}\text { United Nations } \\
\text { Development } \\
\text { Programme } \\
\text { UNDP, } \\
\text { Nations }\end{array}$ \\
\hline
\end{tabular}

\section{RESULTS AND FINDINGS DISCUSSION}

\subsection{Summary Statistics}

Table 2 presents the summary statistics of the variables. The average gross domestic product per capita could be reported as \$ 9.154 per day within the sample period. The average human development index score could also be reported as 0.720 per day. Moreover, the total COVID-19 cases increased at an average of 7 persons per day, and the total deaths recorded per day was approximately four deaths. Regarding stringency (lockdown), countries' stringency index strengthened at an average index score of 3.372 daily.

Table-2. Summary statistics.

\begin{tabular}{c|c|c|c|c|c}
\hline & GDPCAP & HDI & STI & TC & T.D. \\
\hline Mean & 9.154 & 0.720 & 3.372 & 7.102 & 3.730 \\
\hline Median & 9.492 & 0.752 & 4.050 & 7.578 & 3.664 \\
\hline Maximum & 11.669 & 0.953 & 4.605 & 15.914 & 12.300 \\
\hline Minimum & 0.000 & 0.000 & 0.000 & 0.000 & 0.000 \\
\hline Std. Dev. & 1.753 & 0.161 & 1.535 & 3.677 & 3.112 \\
\hline Skewness & -2.815 & -0.804 & -1.515 & -0.376 & 0.402 \\
\hline Kurtosis & 15.249 & 3.790 & 3.695 & 2.398 & 2.218 \\
\hline Jarque-Bera & 334792.200 & 5915.276 & 17799.900 & 1712.948 & 2314.228 \\
\hline Probability & 0.000 & 0.000 & 0.000 & 0.000 & 0.000 \\
\hline Observations & 44216 & 44216 & 44216 & 44216 & 44216 \\
\hline
\end{tabular}

\subsection{Correlation Matrix}

In Table 3, the correlation between the dependent variables and the independent variables are presented. Also, the correlation matrix reveals whether there is multicollinearity in the proposed model for the study. Perhaps, no two independent variables are expected to have high correlation coefficients with the dependent variables. The threshold of the correlation coefficient should be $-/+0.70$ or below to escape the collinearity assumption. Evidence from the table suggests that there is no multicollinearity presence because the variable with the highest correlation coefficient is 0.562 , falling below the threshold of $-/+0.70$ (Sun, Tong, \& Yu, 2002). However, positive and significant correlations were established between HDI, T.C., T.D., and GDPCAP at a 1\% significance level, 
The Economics and Finance Letters, 2021, 8(1): 32-43

respectively. On the other hand, GDPCAP, T.C., T.C., and HDI at a 1\% significance level, respectively. On the contrary, STI showed a negative and significant correlation with both GDPCAP and HDI, respectively.

Table-3. Correlation matrix

\begin{tabular}{l|c|c|c|c|c}
\hline Correlation Probability & GDPCAP & HDI & STI & TC & TD \\
\hline GDPCAP & 1 & & & & \\
\hline HDI & $0.562^{* * *}$ & 1 & & & \\
\hline STI & $-0.038^{* * *}$ & $-0.126^{* * *}$ & 1 & & \\
\hline TC & $0.106^{* * *}$ & $0.108^{* * *}$ & $0.433^{* * *}$ & 1 & \\
\hline TD & $0.153^{* * *}$ & $0.171^{* *} *$ & $0.338^{* * *}$ & $0.918^{* * *}$ & 1 \\
\hline Note $* * *$ signals $1 \%$ significance level. GDPCAP=Gross domestic product per capita HDI=Human Development Index
\end{tabular}

$\mathrm{STI}=$ Stringency Index, TC $=$ Total COVID-19 Cases, TD=Total COVID-19 Deaths

\subsection{The Impact of COVID-19 on Poverty Alleviation}

The analysis results with both ordinary least square and robust least square regression methods suggest that the COVID-19 pandemic inversely impacted poverty alleviation considering the effects of the lockdowns and total confirmed cases in various countries.

Specifically, the lockdown (stringency) deteriorated human capital development by 0.015 and 0.003 index scores, respectively (See Table 4). However, further tightening of the governments' stringency measures could lead to human development deterioration through losing jobs, loss of education, loss in health, and income loss from employable ventures. Also, loss of revenue for governments due to the collapse of businesses and employment could stall the efforts of improving human development through investment in education and health and create a conducive environment for job creation for poverty alleviation.

Interestingly, the total deaths resulting from the COVID-19 pandemic positively impacted poverty alleviation efforts and the human development index. This development implies that the population growth trajectory is not favorable with poverty alleviation; hence, population growth has a social and economic impact on poverty alleviation.

Conversely, the study's findings suggest that by heightening poverty alleviation efforts, economic growth should be consistently increased, and population growth should be stalled. Specifically, a percentage point or $\$ 1$ increase in gross domestic product per capita translates into 0.049 and 0.124 index scores of the human development index; thus, poverty alleviation. Also, a percentage point decrease in population growth could translate into 0.011 and 0.003 index scores of human development hence poverty alleviation.

\subsection{The Impact of COVID-19 on Economic Growth}

Concerning economic growth, the COVID-19 pandemic has a diverse impact on economic growth, considering the level of stringency to curtail the disease's spread to reduce the infection. However, increasing stringency positively supports increasing economic growth where there is an increase in death.

Therefore, a percentage base point increase in the stringency index score could increase economic growth (gross domestic product per capita) by $\$ 0.025$ and $\$ 0.008$, respectively, while reducing the total confirmed cases by $0.030 \%$ and $0.004 \%$, respectively (See Table 5 ).

A percentage base point increase in the index score of human development could lead to $\$ 6.023$ and $\$ 7.257$ in gross domestic product per capita daily to significantly increase economic growth. The pandemic's impact with regards to economic growth on human development within the sample period can be reported as $\$ 6.023$ per capita and $\$ 7.257$ per capita, respectively. More importantly, total deaths recorded regarding the pandemic positively influence economic growth, signaling population reduction's urgency. Moreover, concerted efforts should be garnered towards the trend in population growth. 
The Economics and Finance Letters, 2021, 8(1): 32-43

Table-4. The impact of COVID-19 on poverty alleviation.

\begin{tabular}{|c|c|c|}
\hline Dependent variable & Main & Robust \\
\hline \#NAME? & Ordinary Least square & Robust least square \\
\hline \multirow[t]{2}{*}{ STI } & -0.015 & -0.003 \\
\hline & $(-32.482)^{* * * *}$ & $(-16.178)^{* * * *}$ \\
\hline \multirow[t]{2}{*}{$\mathrm{TC}$} & -0.004 & -0.001 \\
\hline & $(-8.169)^{* * * *}$ & $(-7.646)^{* * * *}$ \\
\hline \multirow[t]{2}{*}{$\mathrm{TD}$} & 0.011 & 0.003 \\
\hline & $(21.614)^{* * * *}$ & $(16.526)^{* * * *}$ \\
\hline \multirow[t]{2}{*}{ GDPCAP } & 0.049 & 0.124 \\
\hline & $(135.774)^{* * * *}$ & $(1005.968)^{* * * *}$ \\
\hline \multirow[t]{2}{*}{$\mathrm{C}$} & 0.308 & -0.43 \\
\hline & $(80.795)^{* * * *}$ & $(-328.280)^{* * *}$ \\
\hline R-squared & 0.344 & 0.725 \\
\hline Adjusted R-squared & 0.344 & 0.725 \\
\hline F-statistics & $5808.076^{* * * *}$ & \\
\hline Rw-squared & & 0.934 \\
\hline Adjusted Rw-squared & & 0.934 \\
\hline Rn-squared statistics & & $1060582.000^{* * * *}$ \\
\hline
\end{tabular}

Table-5. The impact of COVID-19 on economic growth

\begin{tabular}{l|c|c}
\hline Dependent variable & Main & Robust \\
\hline = GDPCAP & Ordinary Least square & Robust least square \\
\hline STI & 0.025 & 0.008 \\
\hline TC & $(4.894)^{* * *}$ & $(7.059)^{* * *}$ \\
\hline TD & -0.030 & $(-3.788)^{* * *}$ \\
\hline HDI & $(-6.034)^{* * *}$ & 0.002 \\
\hline C & $(10.686)^{* * *}$ & $(1.830)^{*}$ \\
\hline R-squared & 6.023 & 7.257 \\
\hline Adjusted R-squared & $(135.774)^{* * *}$ & $(715.981)^{* * *}$ \\
\hline F-statistics & 4.719 & $(451.156)^{* * *}$ \\
\hline Rw-squared & $(120.042)^{* * *}$ & 0.711 \\
\hline Adjusted Rw-squared & 0.319 & 0.711 \\
\hline Rn-squared statistics & 0.319 & 0.940 \\
\hline Not & $5189.115^{* * *}$ & 0.940 \\
\hline
\end{tabular}

Note: *** signals $1 \%$ significance level. GDPCAP $=$ Gross domestic product per capita, HDI=Human Development Index, STI=Stringency Index, TC=Total COVID-19 Cases, TD=Total COVID-19 Deaths. OLS used T-statistics and are in parenthesis, Robust least-square used Z-statistics and are in parenthesis. Observations $=44,216$.

\section{CONCLUSION}

The study aimed to assess the pandemic effects on the global economy, explicitly emphasizing economic growth and poverty alleviation efforts. Conversely, a panel of 170 countries was sampled from 31/12/2020 to 19/10/2020 for the pandemic impact variables (stringency index, total cases, and total deaths) and the data on economic growth (gross domestic product per capita) and poverty alleviation (human development index) used moving averages from 1990 to 2017. To achieve the study's objective, some econometric approaches were used, such as the ordinary least square pooled regression method and the robust least square regression method to estimate the pandemic's long-run impact.

The study found that the pandemic has a significant long-run impact on economic growth and poverty alleviation. To be specific, it was observed that the stringency measures put in place and the number of cases recorded have an adverse impact on poverty alleviation efforts. Whereas a percentage point increase in the stringent measure could lead to 0.015 and 0.003 index scores per day of human development index reduction, which 
means deterioration in the efforts of poverty alleviation, while a percentage point increase in the COVID-19 cases could lead to 0.049 and 0.124 index scores per day of human development index reduction which means deterioration in the efforts of poverty alleviation. Moreover, a percentage point increase in total death interestingly depicts a positive impact on human development hence poverty alleviation. On the other hand, increasing the stringency measures positively associates with economic growth, as revealed by the study's findings. Perhaps, a percentage point increase in the stringency measures could lead to a $\$ 0.025$ and $\$ 0.008$ increase in economic growth per day while reducing the total confirmed cases by $0.030 \%$ and $0.004 \%$, respectively. A percentage base point increase in the index score of human development could lead to $\$ 6.023$ and $\$ 7.257$ in gross domestic product per capita daily to significantly increase economic growth. The pandemic's impact with regards to economic growth on human development within the sample period can be reported as $\$ 6.023$ per capita and $\$ 7.257$ per capita, respectively.

The study's findings suggest that more investment should be channeled towards improvement in human development, specifically health, education, and employment creation to per capita income, translating into increased household consumption and firms' investment to propagate economic growth. Moreover, governments should create significant fiscal space through fiscal and monetary policy support to stimulate the economies for economic recovery is a swift response (World Bank, 2020). A coordinated and comprehensive cross-country policy response is needed for useful and timely recovery (Chudik et al., 2020). Until developing a reliable vaccine, safety protocols such as stringency, social distancing, and personal hygiene practices must be adhered to to save lives, improve health conditions, and save the economies to ensure poverty alleviation.

The global COVID-19 pandemic presents an adverse effect on economies, societies, and vulnerable people. Perhaps, governments, policymakers, and development partners need to tailor swift policies to ensure a robust and sustainable recovery. However, without pragmatic and emergency socio-economic responses, the pandemic's shocks will escalate the global woes, most importantly, endangering livelihoods and lives for a more extended period (United Nations Development Programme, 2020).

The study's limitation emanates from the unavailability of data daily of gross domestic product per capita and human development index, which were used as the dependent variables. Moreover, other factors could affect the relationship between the pandemic and the global economy; hence future studies should introduce variables that can intervene in that relationship. Also, the situation of some countries has changed since this study was conducted. Therefore, the study's time span is a possible limitation that could not curtail the whole dynamics of the pandemic situations.

Funding: This study received no specific financial support.

Competing Interests: The authors declare that they have no competing interests.

Acknowledgement: Both authors contributed equally to the conception and design of the study.

\section{REFERENCES}

Baqaee., D. R., \& Farhi, E. (2020). Nonlinear production networks with an application to the Covid-19 crisis. CEPR Discussion Paper No 14742 .

Bayer, C., Born, B., Luetticke, R., \& Müller, G. (2020). The coronavirus stimulus package: How large is the transfer multipli er? CEPR Working Paper No 14600

Capano, G., Howlett, M., Jarvis, D. S., Ramesh, M., \& Goyal, N. (2020). Mobilizing policy (in) capacity to fight COVID-19: Understanding variations in state responses. Policy and Society, 39(3), 285-308.Available at: https://doi.org/10.1080/14494035.2020.1787628.

Cheng, C., Barcelo, J., Hartnett, A. S., Kubinec, R., \& Messerschmidt, L. (2020). Covid-19 government response event dataset (coronanet v. 1.0). Nature Human Behaviour, 4(7), 756-768. 
The Economics and Finance Letters, 2021, 8(1): 32-43

Chudik, A., Mohaddes, K., Pesaran, M. K., Raissi, M., \& Rebucci, A. (2020). Economic consequences of Covid-19: A counterfactual multi-country analysis. VoxEU.org, 19 October. Retrieved from: https://voxeu.org/article/economicconsequences-covid-19-multi-country-analysis. Retrieved: 22/10/2020.

Elgin, C., Basbug, G., \& Yalaman, A. (2020). Economic policy responses to a pandemic: Developing the COVID-19 economic stimulus index. Columbia: Columbia University.

Fernandes, N. (2020). Economic effects of coronavirus outbreak (COVID-19) on the world economy. Retrieved from: https://papers.ssrn.com/sol3/papers.cfm?abstract_id=3557504.

Gautam, S., \& Hens, L. (2020). SARS-CoV-2 pandemic in India: What might we expect? Berlin: Springer.

Gautam., S., \& Trivedi, U. (2020). Global implications of bio-aerosol in pandemic. Environment, Development and Sustainability, 22(5), 3861-3865.Available at: 10.1007/s 10668-020-00704-2.

Ghosh, I. (2020). The road to recovery: Which Economies are reopening? Visual Capitalist. Retrieved from: https://www.visualcapitalist.com/the-road-to-recovery-which-economies-are-reopening-covid-19/.

Hale, T., Webster, S., Petherick, A., Phillips, T., \& Kira, B. (2020). Oxford COVID-19 government response tracker. Blavatnik School of Government Working Paper 25.

International Monetary Fund (IMF). (2020). World economic outlook, April 2020: The great lockdown. URL: Retrived from: https://www.imf.org/en/Publications/WEO/Issues/2020/04/14/weo-april-2020.

Ludvigson, S. C., Ma, S., \& Ng, S. (2020). COVID-19 and the macroeconomic effects of costly disasters. NBER Working Paper No. 26987.

Mansouri, N. Y., Crookes, R. J., \& Korakianitis, T. (2013). A projection of energy consumption and carbon dioxide emissions in the electricity sector for Saudi Arabia: The case for carbon capture and storage and solar photovoltaics. Energy Policy, 63(C), 681-695.Available at: https://doi.org/10.1016/j.enpol.2013.06.087.

McKibbin, W. J., \& Fernando, R. (2020). The global macroeconomic impacts of COVID-19: Seven scenarios (March 2, 2020). CAMA Working Paper No. 19/2020, Available at SSRN: https://ssrn.com/abstract=3547729 or http://dx.doi.org/10.2139/ssrn.3547729.

Mofijur, M., Fattah, R. I. M., Alam, M. A., Saiful Islam, A. B. M., Ong, H. C., Rahman, S. M. A., . . Mahlia, T. M. I. (2020). Impact of COVID-19 on the social, economic, environmental and energy domains: Lessons learnt from a global pandemic. Sustainable Production and Consumption, 26(April 2021), 343-359.Available at: https://doi.org/10.1016/j.spc.2020.10.016.

Nicola, M. (2020). The socio-economic implications of the coronavirus pandemic (COVID-19): A review. International Journal of Surgery, 78(June 2020), 185-193.Available at: https://doi.org/10.1016/j.ijsu.2020.04.018.

Pagano, M., Wagner, C., \& Zechner, J. (2020). COVID-19, asset prices, and the great reallocation. CEPR Discussion Paper 14773. VoxEU.org. Retrieved from: https://voxeu.org/article/covid-19-asset-prices-and-great-reallocation.

Pirouz, B. (2020). Investigating a serious challenge in the sustainable development process: Analysis of confirmed cases of COVID-19 (New Type of Coronavirus) Through a Binary Classification Using Artificial Intelligence and Regression Analysis. Sustainability, 12(6), 2427.Available at: https://doi.org/10.3390/su12062427.

Salahuddin, M., Gow, J., \& Ozturk, I. (2015). Is the long-run relationship between economic growth, electricity consumption, carbon dioxide emissions and financial development in Gulf Cooperation Council Countries robust? Renewable and Sustainable Energy Reviews, 51, 317-326.Available at: http://dx.doi.org/10.1016/j.rser.2015.06.005.

Sarkodie, S. A., \& Owusu, P. A. (2020). Global assessment of environment, health and economic impact of the novel coronavirus (COVID-19). Environment, Development and Sustainability, Jun 5, 1-1 1.Available at: 10.1007/s 10668-020-0080 1-2.

Statista. (2020). Impact of the coronavirus pandemic on the global economy - Statistics \& Facts. Statista Research Department. Retrieved from: https://www.statista.com/topics/6139/covid-19-impact-on-the-global-economy/.

Sun, Q., Tong, W., \& Yu, Q. (2002). Determinants of foreign direct investment across China. Journal of International Money and Finance, 21(1), 79-113.Available at: https://doi.org/10.1016/S0261-5606(01)00032-8. 
United Nations Development Programme. (2020). Socio-economic impact of COVID 19. United Nations. Retrieved from: https://www.undp.org/content/undp/en/home/coronavirus/socio-economic-impact-of-covid-19.html.

Vitenu-Sackey, P. A., \& Alhassan, N. (2019). How does democracy affect poverty alleviation? Empirical evidence from Africa. International Journal of Management Sciences and Business Research, 8(12), 21-31.

Vitenu-Sackey., P. A. (2020). Financial inclusion and poverty alleviation: The contribution of commercial banks in West Africa. International Journal of Business, Economics and Management, 7(1), 57-70.Available at: 10.18488/journal.62.2020.71.57.70.

Wang, C., Horby, P. W., Hayden, F. G., \& Gao, G. F. (2020). A novel coronavirus outbreak of global health concern. The Lancet, 395, 470-473.Available at: https://doi.org/10.1016/s0140-6736(20)30185-9.

World Bank. (2020). The global economic outlook during the COVID-19 Pandemic: A changed world. Washington, D.C: World Bank.

World Health Organisation. (2020). WHO coronavirus disease (COVID-19) dashboard.

Views and opinions expressed in this article are the views and opinions of the author(s), The Economics and Finance Letters shall not be responsible or answerable for any loss, damage or liability etc. caused in relation to/arising out of the use of the content. 